(c) Cambridge University Press 2012. The online version of this article is published within an Open Access environment subject to the conditions of the Creative Commons Attribution-NonCommercial-ShareAlike licence $<$ http://creativecommons.org/ licenses/by-nc-sa/2.5/>. The written permission of Cambridge University Press must be obtained for commercial re-use.

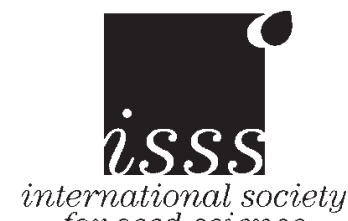

for seed science

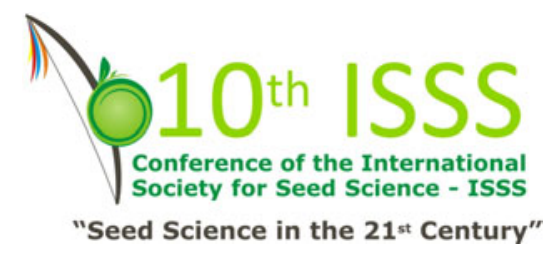

\title{
REVIEW
}

\section{From knowledge-based research towards accurate and rapid testing of seed quality in winter rape}

\author{
Marie-Hélène Wagner $^{1 *}$, Sylvie Ducournau ${ }^{1}$, Aurélia Luciani $^{2}$ and Joël Léchappé ${ }^{1}$ \\ ${ }^{1}$ GEVES, Station Nationale d'Essais de Semences, rue G. Morel, 49071 Beaucouzé, France; ${ }^{2}$ GEVES, \\ rue G. Morel BP 90024, 49071 Beaucouzé, France
}

(Received 23 June 2011; accepted after revision 26 July 2011)

\begin{abstract}
Winter rape has a life cycle which necessitates rapid testing of seed quality for the seed production sector, namely between July after harvest of the previous crop and August when the next crop establishment begins. As this crop is the fourth most important crop in France, and the most important oilseed crop, the French seed testing station GEVES has managed several research programmes to study seed quality in this species. These collaborative programmes have not only associated seed science with seed technology but also informatics and electronic engineering to provide seed testing tools that are already used by the seed sector, such as conductivity, or innovative tools, such as germination time courses monitored by computer imaging. Forthcoming tools have also been looked at in order to control seed storage potential, which is often used nowadays to anticipate the next season. Biochemical markers have been studied, including seed-specific biotinylated proteins or enzymes involved in free radical (reactive oxygen species) scavenging, such as catalase. Both are well correlated with seed ageing and have been tested to provide an ELISA-like assay for seed testing laboratories. Germination monitoring by computer imaging is now used by research and breeding institutes to phenotype varying seed material, including genotype or mutant collec-
\end{abstract}

*Correspondence

Email: Marie-Helene.wagner@geves.fr tions, primed or ageing seed lots, etc. The next step in seed quality testing in oilseed rape is to characterize variation in germination and seed vigour in order to stabilize optimal yield. This aim constitutes a new international project involving high-throughput phenotyping and genotyping of a large collection of genetically diverse rapeseed genotypes (double haploid populations or diverse cultivars).

Keywords: germination, oilseed rape, seed ageing, seed testing

\section{Introduction}

Oilseed rape production has increased all around the world in the past 10 years (USDA, 2011), especially in Europe (30\% of the worldwide production) where this crop protects against water pollution by nitrates by covering soils during the winter season. The increasing demand for biofuel and industrial oils has resulted in a further strong increase in production of this species, by up to almost $70 \%$ in Europe since 2003. More than half of the European production is distributed between Germany and France (Eurostats, 2010). In seed production, France is the top European producer with a positive seed turnover and exports which place it third in the world (ISF, 2009). Export of oilseeds makes up $12 \%$ of total seed exports, behind maize and vegetable seeds (GNIS, 2009). 
Oilseed rape, particularly winter rape, needs fast seed quality testing because of the short time period between harvest and the next sowing. Due to its importance, Groupe d'Etude et de Contrôle des Variétés et Semences (GEVES) has allocated $8 \%$ of its research programmes since 1999 to oilseed rape for both varieties and seeds. Developing better, more reliable and efficient, and less expensive tests is one of the tasks of GEVES Research and Development on seeds. The first studies on oilseed rape were dedicated to understanding how and when seed quality was established on the mother plant. This work monitored seed quality during the maturation stage and, as previously reported for other crops (Bailly et al., 2001), the onset of the ability to germinate and to tolerate desiccation were investigated in relation to abscisic acid (ABA) accumulation (Juricic et al., 1995). For seed producers it was important to identify stages of heterogeneity in seed quality and to anticipate optimum harvest time to achieve high seed quality. The genetic and physiological potential of seeds, interacting with environmental factors prior to or during storage, both determine seed longevity (Bewley and Black, 1994). The main source of quality loss is due to seed ageing, to which oilseeds are particularly susceptible, since their major constituent is lipids, which increase the seeds' predisposition to ageing (Priestley, 1986). Consequently, GEVES programmes on oilseed rape were aimed at maintaining high seed quality and to develop new seed testing methods to provide information in addition to germination analyses performed under ISTA (International Seed Testing Association) international rules.

\section{Oilseed rape seed development and maturation}

Changes in oilseed rape (Brassica napus L.) quality were monitored during seed development and maturation in 2-year field and glasshouse experiments. The onset of the ability to germinate and to tolerate desiccation was investigated in relation to $A B A$ accumulation. Two morphologically different cultivars, an apically dominant one and a bushy type, were studied in this work. Samples of seeds were harvested by hand at different levels from the plants, once a week in the field and every $4 \mathrm{~d}$ in the greenhouse, between days 30 and 90 after flowering. Comparison of development between varieties and years of production was monitored with a temperature scale based on the first flowering of the primary raceme for $50 \%$ of the plant population (Fig. 1). ABA accumulation (Le Page-Degivry et al., 1984) was observed at 700-800 degree days after first flowering (DAF) for both cultivars, the delay between them being related to their flowering precocity. Mass maturity (end of the seedfilling phase) was obtained by fitting seed dry weight
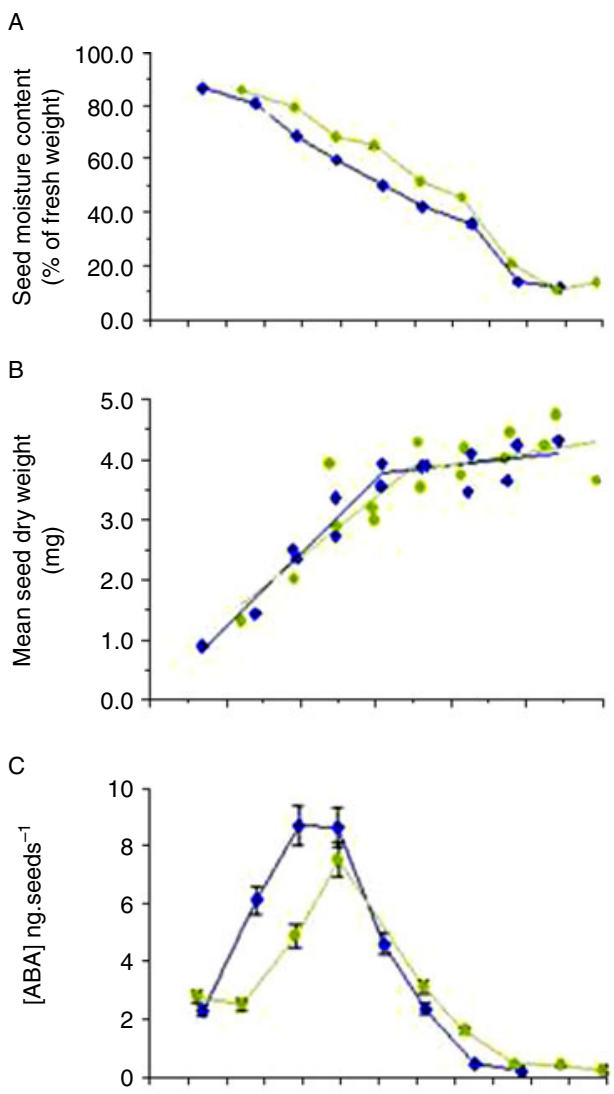

D

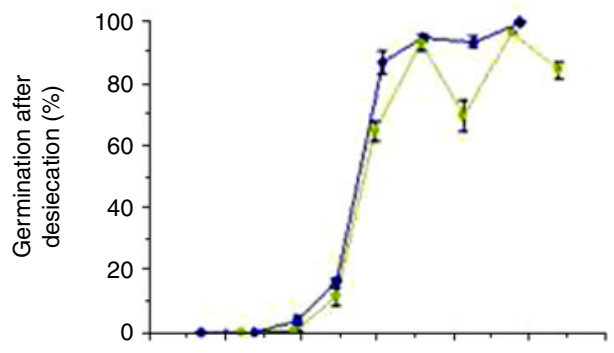

$E$

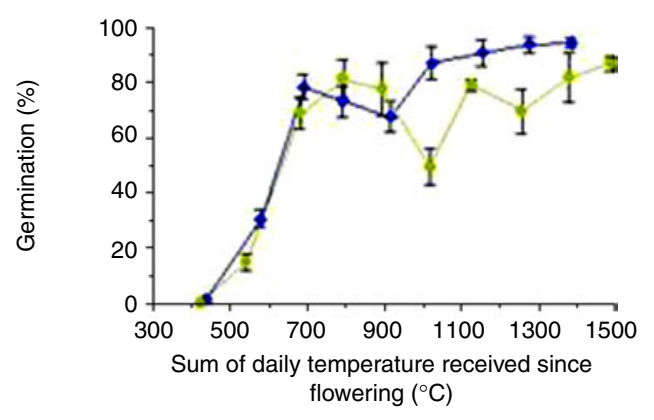

Figure 1. Seed moisture content (a), mean seed dry weight (b), ABA content (c), ability to germinate after seed drying (d) and total germination (e) for two cultivars: apical dominant (diamonds) and bushy type (circles). Seeds were collected weekly during their development in the field in 1998. Means of germination and ABA content are represented $\pm \mathrm{SD}$. (A colour version of this figure can be found online at http://journals.cambridge.org/ssr). 
during development (Fig. 1b) and occurred between 900 DAF and 1000 DAF. Seed moisture contents (wet basis) at this stage were about $45 \%$, while the onset of germinability occurred 200 DAF prior to mass maturity. The ability to germinate was acquired before the end of the seed filling and required no loss in water. However maximum germination after desiccation was obtained in the latest stages of development: 1100-1200 DAF.

Subsequent programmes on oilseed rape produced in the field began with harvest around $900 \mathrm{DAF}$, when mass maturity was completed for seeds, whatever the cultivar. Collaborations with seed physiologists allowed adding some biochemical tests to the global characterization of seed quality. Among them, a number of late embryogenesis abundant proteins (Duval et al., 1997) and enzymes involved in oxidative stress (Bailly, 2004) were studied.

\section{Seed ageing markers for biochemical seed testing}

Biotinylated late embryogenesis abundant (LEA) proteins have been described in many species as seed-specific proteins (Job et al., 2001). They appear during seed development together with the acquisition of desiccation tolerance and are accumulated only in seeds. They disappear quickly when seeds germinate (Alban et al., 2000). They can be detected quite easily owing to the fact that they covalently bind biotin, thereby enabling their detection by avidinbiotin technology. Hence, biotinylated LEA proteins were considered potential candidates for seed quality markers. They were studied over 2 years in oilseed rape during seed development and maturation. The accumulation of biotinylated LEA proteins was concomitant with desiccation tolerance and highly correlated with the maturity of seeds sorted by chlorophyll fluorescence and with the storage potential of seed lots, as determined by controlled deterioration. Thus, the overall results of this study have provided new seed quality markers for oilseed rape with such biotinylated LEA proteins. These proteins can be monitored routinely through an enzyme-linked immunosorbent assay (ELISA), using streptavidin conjugated to peroxidase, and its robustness, sensitivity and simplicity make it an interesting assay for further development in seed testing laboratories. Work is still in progress due to the necessary introduction of a control sample to calibrate serial assays when several seed lots have to be compared. Determination of a threshold for the relative abundance of seed biotinylated proteins is in progress in order to rank seed lots in two or three quality classes.

Over the same period as the above work, seed ageing was widely studied in sunflower seeds (Bailly et al., 2003) through scavenging of reactive oxygen species (ROS) by antioxidant enzymes, or lipid deterioration (Vertucci and Roos, 1990). Since lipids are important storage compounds in rapeseed, the role of antioxidant enzymes in seed quality (Bailly et al., 2002) was investigated a potential marker of seed quality. This was completed using two kinds of material: seed samples with quality adjusted in the laboratory, using a controlled deterioration test; and seed lots of various ages provided by seed companies and stored under two conditions (control: $10^{\circ} \mathrm{C}$, relative humidity (RH) $50 \%$; unfavourable storage: $30^{\circ} \mathrm{C}, 75 \%$ $\mathrm{RH})$. Among the antioxidant enzymes studied in two cultivars, catalase gave the best predictive results for oilseed rape germination after ageing in both artificial and storage deterioration. These results are relevant to recent work showing that molecular events occurring in artificial ageing or natural ageing are similar in Arabidopsis thaliana (Rajjou et al., 2008).

\section{Vigour testing and germination monitoring}

In the 1990s our lab was involved in several ISTA working groups on vigour testing in order to standardize some seed vigour methods and to incorporate them in the ISTA rules (Matthews and Powell, 2005). The conductivity test is the quickest, based on solute leakage from both living and dead cells (Matthews and Powell, 2006), and we have attempted to extend its use to several crops with varying chemical seed composition. Oilseed rape was the first among the main French crops to give encouraging results with leakage measurements. A good correlation was obtained with the standard germination test (Fig. 2) and, hence, seed lot quality can be checked within a shorter time frame. An international comparative test has validated the conductivity method for rape (Wagner and Ducournau, 2007), but further experiments have to be performed in order to obtain correlation with field emergence or seed storage ability

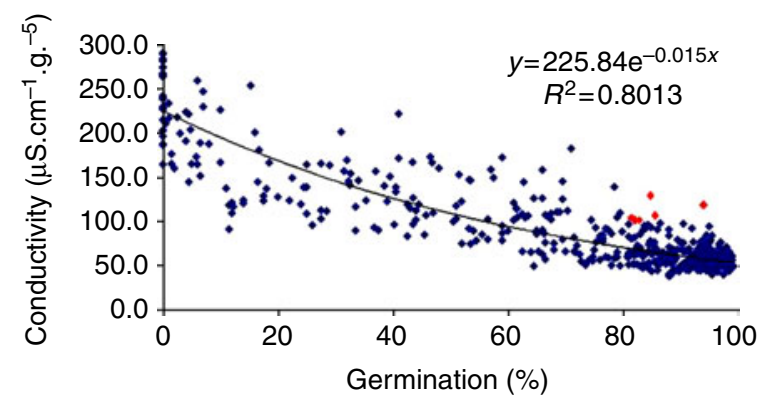

Figure 2. Correlation between standard germination test of oilseed rape (ISTA, 2011) and conductivity test. Data of 520 samples analysed from 2002 to 2010 at the French seed testing station. (A colour version of this figure can be found online at http://journals.cambridge.org/ssr). 
and to determine partition values for interpretation of conductivity results.

Another method to measure seed vigour is to determine rate and uniformity of seed germination and seedling growth. This has been achieved using a prototype computer imaging system described by Ducournau et al. (2004, 2005), with a single camera above a Jacobsen table. The complete monitoring system has been improved to study imbibition, germination and the first step of seedling elongation of 20 species, including oilseed rape. Two Jacobsen incubators were exposed to four colour cameras each in order to automate germination time courses for a large number of seeds (up to 400 per camera).

In order to compare controlled deterioration methods in oilseed rape, a large screening with this

Table 1. Main characteristics obtained at $20^{\circ} \mathrm{C}$ for 42 samples of oilseed rape. Seed lots with the same letter are from the same cultivar. Values are means of 50 seeds \pm standard error of the means (SEM); the general mean is of the 42 lots \pm standard deviation (SD)

\begin{tabular}{|c|c|c|c|c|c|c|}
\hline Harvest year & $\begin{array}{l}\text { Seed } \\
\text { lot }\end{array}$ & $\begin{array}{l}\text { Volume } \pm \\
\text { SEM }\left(\mathrm{mm}^{3}\right)\end{array}$ & $\begin{array}{l}\text { Imbibition after } \\
8 \mathrm{~h} \pm \text { SEM }(\%)\end{array}$ & $\begin{array}{l}\text { MGT } \pm \\
\text { SEM (h) }\end{array}$ & $\begin{array}{c}\text { Germination } \\
(\%)\end{array}$ & $\begin{array}{l}\text { Uniformity } \\
\text { T90-T10 (h) }\end{array}$ \\
\hline 2000 & $\mathrm{C} 2$ & $7.1 \pm 0.2$ & $24 \pm 1.1$ & $49.3 \pm 1.1$ & 85- & 42.4 \\
\hline \multirow[t]{2}{*}{2001} & B4 & $9.2 \pm 0.3$ & $25 \pm 1.2$ & $50.3 \pm 2.0$ & 70 & 59.1 \\
\hline & G2 & $8.7 \pm 0.3$ & $22 \pm 1.8$ & $45.6 \pm 1.9$ & 82 & 49.2 \\
\hline \multirow[t]{9}{*}{2002} & A2 & $6.9 \pm 0.2$ & $29 \pm 1.4$ & $37.4 \pm 1.5$ & 96 & 28.0 \\
\hline & A3 & $7.4 \pm 0.2$ & $27 \pm 1.3$ & $39.9 \pm 1.4$ & 88 & 45.7 \\
\hline & A4 & $6.0 \pm 0.2$ & $23 \pm 1.3$ & $40.5 \pm 1.2$ & 100 & 20.5 \\
\hline & A5 & $6.5 \pm 0.2$ & $38 \pm 2.0$ & $30.6 \pm 1.2$ & 100 & 19.3 \\
\hline & A6 & $6.4 \pm 0.2$ & $37 \pm 1.5$ & $29.5 \pm 1.0$ & 100 & 15.0 \\
\hline & B5 & $6.0 \pm 0.1$ & $29 \pm 1.6$ & $44.9 \pm 1.7$ & 96 & 37.0 \\
\hline & C3 & $6.5 \pm 0.1$ & $26 \pm 1.0$ & $40.3 \pm 1.1$ & 97 & 32.5 \\
\hline & G1 & $6.5 \pm 0.2$ & $24 \pm 1.5$ & $43.1 \pm 1.3$ & 94 & 31.5 \\
\hline & G3 & $8.1 \pm 0.3$ & $28 \pm 1.9$ & $36.3 \pm 1.5$ & 96 & 32.8 \\
\hline \multirow[t]{14}{*}{2003} & B1 & $5.9 \pm 0.2$ & $32 \pm 1.8$ & $36.0 \pm 1.3$ & 100 & 21.5 \\
\hline & B2 & $6.9 \pm 0.2$ & $32 \pm 1.5$ & $32.6 \pm 1.3$ & 96 & 24.0 \\
\hline & B3 & $5.5 \pm 0.2$ & $30 \pm 1.7$ & $42.2 \pm 1.6$ & 98 & 33.0 \\
\hline & $\mathrm{C} 1$ & $5.2 \pm 0.1$ & $31 \pm 1.6$ & $34.2 \pm 1.1$ & 93 & 38.0 \\
\hline & D1 & $5.4 \pm 0.1$ & $33 \pm 1.4$ & $39.6 \pm 1.0$ & 96 & 25.0 \\
\hline & D2 & $5.3 \pm 0.1$ & $38 \pm 1.5$ & $43.2 \pm 1.1$ & 91 & 40.9 \\
\hline & D3 & $4.7 \pm 0.4$ & $32 \pm 1.4$ & $45.5 \pm 1.7$ & 98 & 33.7 \\
\hline & D4 & $5.5 \pm 0.1$ & $27 \pm 1.1$ & $44.2 \pm 2.0$ & 90 & 45.0 \\
\hline & E1 & $5.6 \pm 0.2$ & $36 \pm 1.4$ & $45.6 \pm 1.9$ & 76 & 56.6 \\
\hline & E2 & $4.8 \pm 0.2$ & $42 \pm 1.9$ & $40.8 \pm 1.7$ & 80 & 56.3 \\
\hline & F1 & $6.0 \pm 0.2$ & $38 \pm 1.6$ & $33.3 \pm 1.5$ & 96 & 29.5 \\
\hline & F2 & $5.0 \pm 0.2$ & $46 \pm 2.4$ & $33.1 \pm 1.4$ & 100 & 20.2 \\
\hline & F3 & $5.1 \pm 0.1$ & $38 \pm 1.8$ & $35.5 \pm 1.5$ & 100 & 26.5 \\
\hline & $\mathrm{P}$ & $9.2 \pm 0.3$ & $17 \pm 1.2$ & $38.0 \pm 1.5$ & 100 & 21.3 \\
\hline \multirow[t]{2}{*}{2004} & M & $5.9 \pm 0.1$ & $23 \pm 1.6$ & $30.9 \pm 1.3$ & 96 & 28.5 \\
\hline & $\mathrm{N}$ & $7.4 \pm 0.3$ & $21 \pm 1.6$ & $32.4 \pm 1.5$ & 94 & 34.0 \\
\hline \multirow[t]{3}{*}{2005} & A1 & $7.6 \pm 0.2$ & $28 \pm 1.2$ & $31.7 \pm 0.9$ & 98 & 20.0 \\
\hline & $\mathrm{L}$ & $7.1 \pm 0.2$ & $22 \pm 1.5$ & $35.4 \pm 1.7$ & 94 & 45.0 \\
\hline & $\mathrm{O}$ & $8.3 \pm 0.3$ & $30 \pm 1.5$ & $28.4 \pm 1.2$ & 98 & 13.7 \\
\hline \multirow[t]{4}{*}{2006} & I & $7.5 \pm 0.3$ & $22 \pm 1.7$ & $29.8 \pm 1.8$ & 100 & 30.6 \\
\hline & J & $6.6 \pm 0.2$ & $15 \pm 1.0$ & $30.4 \pm 1.4$ & 100 & 26.0 \\
\hline & $\mathrm{K}$ & $8.7 \pm 0.3$ & $15 \pm 1.4$ & $31.2 \pm 1.6$ & 96 & 30.7 \\
\hline & Q & $9.1 \pm 0.3$ & $28 \pm 1.4$ & $31.6 \pm 1.6$ & 98 & 26.3 \\
\hline \multirow[t]{5}{*}{2007} & H1 & $6.3 \pm 0.2$ & $27 \pm 1.8$ & $29.2 \pm 1.1$ & 100 & 17.2 \\
\hline & $\mathrm{H} 2$ & $6.4 \pm 0.2$ & $34 \pm 1.7$ & $28.0 \pm 1.3$ & 94 & 24.0 \\
\hline & H3 & $6.9 \pm 0.2$ & $27 \pm 1.7$ & $29.8 \pm 1.1$ & 98 & 22.8 \\
\hline & $\mathrm{H} 4$ & $7.0 \pm 0.3$ & $28 \pm 2.0$ & $27.9 \pm 1.0$ & 96 & 17.8 \\
\hline & H5 & $6.4 \pm 0.6$ & $29 \pm 1.6$ & $32.8 \pm 1.2$ & 100 & 22.5 \\
\hline \multirow[t]{2}{*}{2008} & $\mathrm{R}$ & $5.5 \pm 0.2$ & $25 \pm 1.5$ & $31.0 \pm 1.3$ & 98 & 25.5 \\
\hline & $\mathrm{s}$ & $7.5 \pm 0.2$ & $26 \pm 1.3$ & $34.2 \pm 1.2$ & 98 & 18.8 \\
\hline General mean \pm SD & & $6.7 \pm 1.2$ & $29 \pm 7$ & $36.3 \pm 6.3$ & 94.7 & 30.7 \\
\hline Maximal range & & $4.7-9.2$ & $15-46$ & $27.9-50.3$ & $70-100$ & $13.7-59.1$ \\
\hline
\end{tabular}

MGT, mean germination time. 
computer video equipment was carried out to select 15 samples from the same range of vigour. The germination time courses of 42 seed lots were compared and the related parameters, such as percentiles, mean germination time (MGT), final germination, etc., were obtained with a high precision due to the high frequency of images. The older samples displayed the longer germination times and the highest heterogeneity (Table 1). Nevertheless, despite being 7 years old, two seed lots from the same cultivar harvested in 2002 (A5 and A6, in bold in Table 1) germinated as rapidly and homogeneously as more recent seed lots. The germination monitors are used to answer seed companies' requests and to rank seed lots according to their rate and uniformity of germination, but they are also useful for seed research to phenotype mutants or genotypes during this first stage of plant development (Joosen et al., 2010). The tools have already been used for phenotyping a model crop for its establishment, and some quantitative trait loci related to germination and heterotrophic growth have been determined (Menna-Barreto-Dias et al., 2011).

In the experiments presented here tools have been developed for analysing seed quality, which are faster, more reliable and less empirical than the existing tools. They have also contributed to an increased understanding of the seed physiology of oilseed rape. Evidently, the testing methods based on seed markers need further development before becoming routine. In addition, seed science in progress will provide new approaches to seed testing.

\section{Acknowledgements}

We would like to acknowledge Dr Alison Powell, University of Aberdeen for her helpful review of this paper. As methodological research in our laboratory is carried out through much collaboration, we are grateful to many people. Chronologically, we thank Elisabeth Le Page-Degivry and Ginette Garello (Universite de Nice), the first to join us and work on rapeseed. Then we collaborated with Dominique and Claudette Job (CNRS), Olivier Leprince and Pascale Satour (Agrocampus, Université d'Angers), Christophe Bailly and Françoise Corbineau (Université Pierre et Marie Curie) and, more recently, Nathalie Nesi and Michel Renard (INRA), we thank all of them. We have always worked with seed companies from which some people are also to be thanked: Bernard Baduffle, Armand Feutry, Elisabeth Lasserre, AnneSophie Lory, Isabelle Pauchet and François Poutoire. Our colleagues from GEVES or INRA whom we enjoy working with: Didier Demilly, Carolyne Dürr, Marie-Claire Gâtineau and Lydie Ledroit. Finally, we proudly remember Professor D. Côme who transmitted to us his passion for seed science. The various research programmes were carried out with financial support from the Ministère de l'Agriculture, de l'Alimentation, de la Pêche, de la Ruralité et de l'Aménagement du territoire, and the forthcoming international project ANR-10-KBBE-002 with public funds allocated to research and development from Agence Nationale de la Recherche (ANR).

\section{References}

Alban, C., Job, D. and Douce, R. (2000) Biotin metabolism in plants. Annual Review of Plant Biochemistry and Plant Molecular Biology 51, 17-47.

Bailly, C. (2004) Active oxygen species and antioxidants in seed biology. Seed Science Research 14, 93-107.

Bailly, C., Audigier, A., Ladonne, F., Wagner, M.H., Coste, F., Corbineau, F. and Côme, D. (2001) Changes in oligosaccharide content and antioxidant enzyme activities in developing bean seeds as related to acquisition of drying tolerance and seed quality. Journal of Experimental Botany 52, 701-708.

Bailly, C., Bogatek-Leszczynska, R., Côme, D. and Corbineau, F. (2002) Changes in activities of antioxidant enzymes and lipoxygenase during growth of sunflower seedlings from seeds of different vigour. Seed Science Research 12, 47-55.

Bailly, C., Leymarie, J., Rousseau, S., Côme, D., Feutry, A. and Corbineau, F. (2003) Sunflower seed development as related to antioxidant enzyme activities. pp. 69-75 in Nicolas, G.; Bradford, K.; Côme, D.; Pritchard, H. (Eds) The biology of seeds: recent research advances. Oxon, UK, CABI Publishing.

Bewley, D. and Black, M. (1994) Seeds. Physiology of development and germination. New-York, Plenum Press.

Ducournau, S., Feutry, A., Plainchault, P., Revollon, P., Vigouroux, B. and Wagner, M.H. (2004) An image acquisition system for automated monitoring of the germination rate of sunflower seeds. Computers and Electronics in Agriculture 44, 189-202.

Ducournau, S., Feutry, A., Plainchault, P., Revollon, P. Vigouroux, B. and Wagner, M.H. (2005) Using artificial vision to monitor germination time course of sunflower (Helianthus annuus L.) seeds. Seed Science and Technology 33, 329-340.

Duval, M., Dehaye, L., Alban, C., Derose, R., Douce, R., Job, C. and Job, D. (1997) The role of protein biotinylation in the development and germination of seeds. pp. 33-43 in Ellis, R.H.; Black, M.; Murdoch, A.J.; Hong, T.D. (Eds) Basic and applied aspects of seed biology. Dordrecht, Kluwer Academic Publishers.

Eurostats (2010) Statistiques agricoles, principaux tableaux. Available at http://epp.eurostat.ec.europa.eu/portal/ page/portal/agriculture/data/main_tables (accessed 20 March 2011).

GNIS (Groupement national interprofessionnel des semences et plants) (2009) Le chiffre d'affaires du secteur semences et plants-campagne 2008-2009. Répartition du chiffre d'affaires par groupe d'espèces. Available at http: / / www.gnis.fr/index/action/page/id/25/title/ Le-chiffre-d-affaires-semences-et-plants--Campagne2008-09 (accessed 15 April 2009). 
ISF (International Seed Federation) (2009) Seed statistics. Seed exports in selected countries in 2008. Available at http://www.worldseed.org/isf/seedstatistics.html (accessed 15 April 2009).

ISTA (2011) International rules for seed testing. Bassersdorf, Switzerland, International Seed Testing Association.

Job, C., Laugel, S., Duval, M., Gallardo, K. and Job, D. (2001) Biochemical characterization of atypical biotinylation domains in seed proteins. Seed Science Research 11, 149-161.

Joosen, R.V.L., Kodde, J., Willems, L.A.J., Ligterink, W., van der Plas, L.H.W. and Hilhorst, H.W.M. (2010) Germinator: a software package for high-throughput scoring and curve fitting of Arabidopsis seed germination. Plant Journal 62, 148-159.

Juricic, S., Orlando, S. and Le Page-Degivry, M.T. (1995) Genetic and ontogenic changes in sensitivity to abscisic acid in Brassica napus seeds. Plant Physiology and Biochemistry 33, 593-598.

Le Page-Degivry, M.T., Duval, D., Bulard, C. and Delaage, M. (1984) A radioimmunoassay for abscisic acid. Journal of Immunological Methods 67, 119-128.

Matthews, S. and Powell, A.A. (2005) Towards the validation of the controlled deterioration vigour test for small seeded vegetables. Seed Testing International 129, 21-23.
Matthews, S. and Powell, A.A. (2006) Electrical conductivity test: physiological basis and use. Seed Testing International 131, 32-35.

Menna-Barreto-Dias, P., Brunel, S., Dürr, C., Huguet, T., Demilly, D., Wagner, M-H. and Teulat-Merah, B. (2011) QTL analysis of seed germination and pre-emergence growth at extreme temperatures in Medicago truncatula. Theoretical and Applied Genetics 122, 429-444.

Priestley, D.A. (1986) Seed aging. Implications for seed storage and persistence in soil. Ithaca, USA, Cornell University Press.

Rajjou, L., Lovigny, Y., Groot, S.P.C., Belghazi, M., Job, C. and Job, D. (2008) Proteome-wide characterization of seed aging in Arabidopsis: A comparison between artificial and natural aging protocols. Plant Physiology 148, 620-641.

USDA (United States Department of Agriculture) (2011) Economics, statistics and market information system. Available at http://usda.mannlib.cornell.edu/usda/ fas / oilseed-trade / /2010s / 2011/ oilseed-trade-03-102011.pdf (accessed 20 March 2011).

Vertucci, C.W. and Roos, E. (1990) Theoretical basis of protocols for seed storage. Plant Physiology 94, 1019-1023.

Wagner, M.H. and Ducournau, S. (2007) Conductivity testing for oilseed rape seeds. Seed Testing International 133, 40-41. 